\title{
Outer Membrane Protein 25 of Brucella Activates Mitogen-Activated Protein Kinase Signal Pathway in Human Trophoblast Cells
}

\author{
Jing Zhang't, Yu Zhang't, Zhiqiang $\mathrm{Li}^{2}$, Jing Liu', Xuehua Shao ${ }^{3}$, Changxin Wu', \\ Yong Wang ${ }^{1}$, Kaisheng Wang ${ }^{1}$, Tiansen Li ${ }^{1}$, Laizhen Liu ${ }^{1 *}$, Chuangfu Chen ${ }^{1}$ and Hui Zhang ${ }^{1 *}$ \\ ${ }^{1}$ College of Animal Science and Technology, Shihezi University, Shihezi, China, ${ }^{2}$ School of Biotechnology and Food, \\ Shangqiu Normal University, Shangqiu, China, ${ }^{3}$ Institute of Fruit Tree Research, Guangdong Academy of Agricultural \\ Sciences, Key Laboratory of South Subtropical Fruit Tree Biology and Genetic Resources Utilization, Ministry of Agriculture, \\ Guangzhou, China
}

\section{OPEN ACCESS}

Edited by:

Jiabo Ding,

China Institute of Veterinary Drug Control, China

Reviewed by: Yongqun "Oliver" He, University of Michigan Health System, United States Kenneth James Genovese, Agricultural Research Service (USDA), United States

*Correspondence:

Laizhen Liu

liulaizhen2013@sina.com;

Hui Zhang

allanzhh@sohu.com

tThese authors have contributed equally to this work.

Specialty section:

This article was submitted to Veterinary Infectious Diseases,

a section of the journal Frontiers in Veterinary Science

Received: 21 September 2017 Accepted: 01 November 2017 Published: 13 December 2017

Citation:

Zhang J, Zhang Y, Li Z, Liu J, Shao X, Wu C, Wang Y, Wang K, Li T, Liu L, Chen C and Zhang H (2017) Outer Membrane Protein 25 of Brucella Activates Mitogen-Activated Protein Kinase Signal Pathway in Human Trophoblast Cells.

Front. Vet. Sci. 4:197. doi: 10.3389/fvets.2017.00197
Outer membrane protein 25 (OMP25), a virulence factor from Brucella, plays an important role in maintaining the structural stability of Brucella. Mitogen-activated protein kinase (MAPK) signal pathway widely exists in eukaryotic cells. In this study, human trophoblast cell line HPT-8 and BALB/c mice were infected with Brucella abortus 2308 strain (S2308) and 2308 $\Delta$ Omp25 mutant strain. The expression of cytokines and activation of MAPK signal pathway were detected. We found that the expressions of tumor necrosis factor- $\alpha$, interleukin-1, and interleukin-10 (IL-10) were increased in HPT-8 cells infected with S2308 and 2308 $\Delta$ Omp25 mutant. S2308 also activated p38 phosphorylation protein, extracellular-regulated protein kinases (ERK), and Jun-N-terminal kinase (JNK) from MAPK signal pathway. 2308 Omp25 could not activate p38, ERK, and JNK branches. Immunohistochemistry experiments showed that S2308 was able to activate phosphorylation of p38 and ERK in BABL/c mice. However, 2308 Omp25 could weakly activate phosphorylation of $\mathrm{p} 38$ and ERK. These results suggest that Omp25 played an important role in the process of Brucella activation of the MAPK signal pathway.

Keywords: Brucella, 2308دOmp25, mitogen-activated protein kinase, cytokines, HPT-8 cells

\section{INTRODUCTION}

Brucella spp. are Gram-negative facultative intracellular pathogens that can cause diseases of worldwide significance $(1,2)$. Brucella can cause epididymitis, orchitis, or abortion in animals (3). Infection in humans can cause fever or arthritis $(4,5)$. It resulted in heavy economic losses (6).

There are three groups of major outer membrane proteins (Omps) in Brucella (7). Group 1 Omps consist of two major Omps: Omp10 and Omp19. Group 2 Omps consist of two major Omps: Omp2a and Omp2b. Group 3 Omps consist of two major Omps: outer membrane protein 25 (Omp25) and Omp31. Omp25 was a primary protein that was released by Brucella when it invaded host cells (8). Omp25 was involved in attachment or invasion to the host cells and intracellular survival or reproduction of Brucella, which plays an important role in Brucella virulence. Omp25 mutant was attenuated in animals $(9,10)$. Therefore, Omp25 is an important virulence factor of Brucella.

Mitogen-activated protein kinase (MAPK) is one signal transduction pathway in organisms. It is associated with many profiles and processes of the cell, such as auxesis, development, proliferation, 
differentiation, and apoptosis (11). MAPK includes four subfamilies: p38, ERK1/2, Jun-N-terminal kinase (JNK), and ERK5 (12). MAPK is implicated in bacterial pathogenesis as demonstrated by the induction of inhibition of ERK1/2 and p38 branches during infection with Salmonella typhimurium (13), Yersinia (14, 15), Listeria monocytogens $(16,17)$, and Mycobacterium (18). In the inflammatory response, MAPK signal pathway can mediate secretion of IL-8, interleukin-10 (IL-10), tumor necrosis factor- $\alpha$ (TNF- $\alpha$ ), and other cytokines by epithelial cells (19). In this report, we used S2308 and $2308 \Delta$ Omp 25 to infect HPT- 8 cells and mice, and the expression of cytokines were detected. In addition, we analyzed the effects of Omp25 on the MAPK signal pathway, with the aim to understand the function of Omp25 in the pathogenesis of Brucella.

\section{MATERIALS AND METHODS}

\section{Ethics Statement}

All animal experiments were performed in strict accordance with the Experimental Animal Regulation Ordinances defined by the China National Science and Technology Commission. The study was approved by the Institutional Committee of Post-Graduate Studies and Research at Shihezi University, China (No. 2012-9). Animals are provided with humane care and healthful conditions. All efforts were made to minimize animal suffering.

\section{Bacterial Strains and Cell Line}

Brucella abortus 2308 strain was obtained from the Center of Chinese Disease Prevention and Control (Beijing, China). $2308 \Delta$ Omp25 mutant was constructed and kept by our laboratory. Brucella was cultured in tryptic soy agar or tryptic soy broth (TSB) (Sigma, St. Louis, MO, USA) at $37^{\circ} \mathrm{C}$ with $5 \% \mathrm{CO}_{2}$ (vol/vol). The human trophoblast cell line HPT-8 (obtained from Cell Resource Center, IBMS, CAMS/PUMC, Beijing, China) was cultured in Dulbecco's modified Eagle's medium (DMEM; Gibco Life Technologies, Rockville, MD, USA) supplemented with $10 \%$ fetal bovine serum (FBS; Gibco Life Technologies, Rockville, MD, USA) at $37^{\circ} \mathrm{C}$ with $5 \% \mathrm{CO}_{2}$ (vol/vol).

\section{Mice}

Six-week-old BALB/c female mice were obtained from the Experimental Animal Center of the Academy of Military Medical Science (Beijing, China). Animals were maintained in barrier housing with filtered inflow air in a restricted-access room in pathogen-limited conditions. All experimental procedures and animal care were performed in compliance with institutional animal care regulations. And all experimental procedures and animal care were performed in Biosafety Level 3 Laboratory.

\section{Brucella Cell Infection Assay}

HPT-8 cells were infected with S2308 and 2308 $\Delta$ Omp25, as previously described (20). The bacteria for infection studies were prepared before the experiment was executed. S2308 and $2308 \Delta \mathrm{Omp} 25$ were cultured in TSB at $37^{\circ} \mathrm{C}$ with $5 \% \mathrm{CO}_{2}$ (vol/vol) until logarithmic growth phase. Then, $2 \times 10^{6}$ cells/ well were cultured in 6-well plates for $24 \mathrm{~h}$ at $37^{\circ} \mathrm{C}$ under $5 \%$ $\mathrm{CO}_{2}$, and then infected with $\mathrm{S} 2308$ or $2308 \Delta \mathrm{Omp} 25$ at a multiplicity of infection (MOI) of 100 bacteria per cell. Culture plates were centrifuged at $350 \times g$ for $5 \mathrm{~min}$ at room temperature. At $45 \mathrm{~min}$ post-infection, the cells were washed thrice with medium without antibiotics and then incubated with $50 \mu \mathrm{g} / \mathrm{mL}$ of gentamicin (Invitrogen, Carlsbad, CA, USA) for $1 \mathrm{~h}$ to kill extracellular bacteria. Afterward, the medium was removed and replaced with fresh DMEM with $10 \%$ FBS containing $25 \mu \mathrm{g} / \mathrm{mL}$ gentamicin (defined as time 0). Uninfected cells were used as control.

\section{Detection of Cytokines}

HPT-8 cells were infected with S2308 and 2308 OOmp25 according to the above description. At $4,8,24$, and 48 h postinfection, supernatant was collected and filtered with $0.22 \mu \mathrm{m}$ filter membrane (Millipore, MA, USA). Then, supernatant was centrifuged at $16,000 \times g$ for $15 \mathrm{~min}$ at $4^{\circ} \mathrm{C}$. The levels of TNF- $\alpha$, interleukin-1 (IL-1), and IL-10 were measured using an ELISA Quantikine Human Kit (R\&D Systems, Minneapolis, MN, USA) according to the manufacturer's instructions. All assays were performed in triplicate and the concentration of each cytokine in the cell supernatant was calculated using a linear regression equation obtained from the absorbance values of standards, according to the manufacturer's protocol. All assays were performed three times.

\section{Determination of MAPK Branches Associated with the Secretion of TNF- $\alpha$}

To confirm the MAPK signal pathway associated with the secretion of TNF- $\alpha$, HPT- 8 cells were pre-treated with p38 inhibitor $(10 \mu \mathrm{M})$, or JNK inhibitor $(10 \mu \mathrm{M})$ at $37^{\circ} \mathrm{C}$ for $1 \mathrm{~h}$ and then infected with S2308 or $2308 \Delta$ Omp25 at a 100:1 MOI according to the above description. At $4,8,24$, and $48 \mathrm{~h}$ post-infection, supernatant was collected and measured the levels of TNF- $\alpha$ according to the above description. All assays were performed three times.

\section{Western Blotting Analysis}

HPT- 8 cells were infected with S2308 and 2308 $\Delta$ Omp 25 according to the above description. The activation of p38, ERK1/2, and JNK was detected in infected cells, as previously described (21). Briefly, at $24 \mathrm{~h}$ post-infection, supernatant was discarded and cells were lysed in ice-cold Radio Immunoprecipitation Assay Lysis Buffer (Beyotime Institute of Biotechnology, Shanghai, China) for $30 \mathrm{~min}$, then centrifuged at $16,000 \times g$ for $30 \mathrm{~min}$ at $4^{\circ} \mathrm{C}$. The supernatant was collected and concentration was detected with BCA protein assay kit (Sangon Biotech, Shanghai, China). $500 \mu$ g protein samples separated by $12 \%$ SDS-PAGE and electro-transferred to a nitrocellulose membrane using a Mini Trans-Blot Cell (Bio-Rad, Hercules, CA, USA) at $200 \mathrm{~mA}$ for $1 \mathrm{~h}$. Unbound sites on the membrane were blocked in 5\% nonfat milk in Tris-buffered saline Tween-20 (TBST) buffer for $1 \mathrm{~h}$ at room temperature. Then, the membrane was washed three times with TBST buffer and incubated with rabbit anti-human anti-p38, 
anti-ERK, or anti-JNK polyclonal antibody (pAb; diluted 1:1,000; Bioworld, Minneapolis, MN, USA) at room temperature for $1 \mathrm{~h}$. After being washed three times, the membrane was incubated with peroxidase conjugated goat anti-rabbit IgG for $1 \mathrm{~h}$ at room temperature. After a further washing step, bound conjugate was visualized with an ECL Plus Western Blotting Substrate kit (Thermo Fisher Scientific, USA). All assays were performed three times.

\section{Brucella Infection in Mice and Cytokine Measurement}

$\mathrm{BALB} / \mathrm{c}$ mice were infected with Brucella as previously described (22). Briefly, 6 -week-old BALB/c female mice ( $n=5$ per group) were randomly divided into three groups. Group 1 and 2 were inoculated intraperitoneally (i.p.) with $200 \mu \mathrm{L}$ phosphatebuffered saline (PBS; Sigma-Aldrich, MO, USA) containing $1 \times 10^{6} \mathrm{CFU}$ of S2308 or $2308 \Delta \mathrm{Omp} 25$, respectively, group 3 was inoculated i.p. with $200 \mu \mathrm{L}$ PBS as negative control. Serum samples were obtained from peripheral blood of immunized mice 2, 4, 6, 8, and 10 weeks post-immunization (23). Serum samples were diluted with sample diluent buffer (1:5). The level of TNF- $\alpha$ was measured using an ELISA Quantikine Mouse Kit (R\&D Systems, Minneapolis, MN, USA) according to the manufacturer's instructions. All assays were performed in triplicate and the concentration of each cytokine in the cell supernatant was calculated using a linear regression equation obtained from the absorbance values of standards, according to the manufacturer's protocol. All assays were performed three times.

\section{Tissue Specimens}

BALB/c mice ( $n=25$ per group) were inoculated with S2308 and $2308 \Delta$ Omp 25 according to the above description. At 2, 4, 6,8 , and 10 weeks post-immunization, mice were euthanized and uteruses were removed aseptically. The uteruses were collected, formalin-fixed, and paraffin-embedded, as previously described (24).

\section{Immunohistochemistry}

The immunohistochemistry assay was performed as previously described (25). Briefly, the embedded paraffin will be serial sectioned by slicer, with a thickness of $5 \mu \mathrm{m}$ and mounted on slide glasses coated with poly-L-lysine (Beyotime Institute of Biotechnology, Shanghai, China). Subsequently, the tissue sections were routine deparaffinized and dehydrated with xylene and ethanol. After three times washed with distilled water, the tissue sections were microwaved in $10 \mathrm{mM}$ citrate buffer (pH 6.0; Sigma-Aldrich, MO, USA) at $95^{\circ} \mathrm{C}$ for $10 \mathrm{~min}$ for antigen retrieval and naturally cooled at room temperature. Then, the endogenous peroxidase activity was blocked by incubation with $3 \%$ hydrogen peroxide buffer (Sigma-Aldrich, MO, USA) for $10 \mathrm{~min}$ at room temperature. The tissue sections were incubated overnight at $4^{\circ} \mathrm{C}$ with primary antibody (rabbit anti-mouse antip38 or anti-ERK pAb; dilution 1:200; Bioworld, Minneapolis, MN, USA). Subsequently, the sections were washed three times with PBS, each time for $5 \mathrm{~min}$. The sections were incubated at $37^{\circ} \mathrm{C}$ for $30 \mathrm{~min}$ with the secondary antibody (biotinylated goat anti-rabbit IgG; dilution 1:500; ZSGB-BIO, Beijing, China) followed by washing three times with PBS, each time for $5 \mathrm{~min}$. Finally, the tissue sections were dropwise added $100 \mu \mathrm{L}$ DAB Plus Substrate buffer (Thermo Fisher Scientific, USA) containing $2 \%(\mathrm{v} / \mathrm{v})$ DAB Plus Chromogen (Thermo Fisher Scientific, USA), and the nuclei were counterstained with hematoxylin. The tissue sections were dehydrated, transparented, and sealed with ethanol, xylene, and Neutral gum.

\section{Statistical Analysis}

Cytokine production was expressed as the mean cytokine concentration \pm SD. Statistical analysis was performed with Student's unpaired $t$-test. The differences between groups were

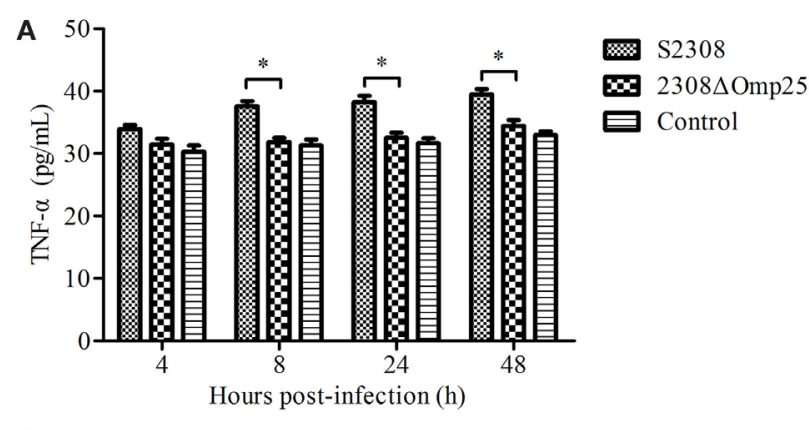

B
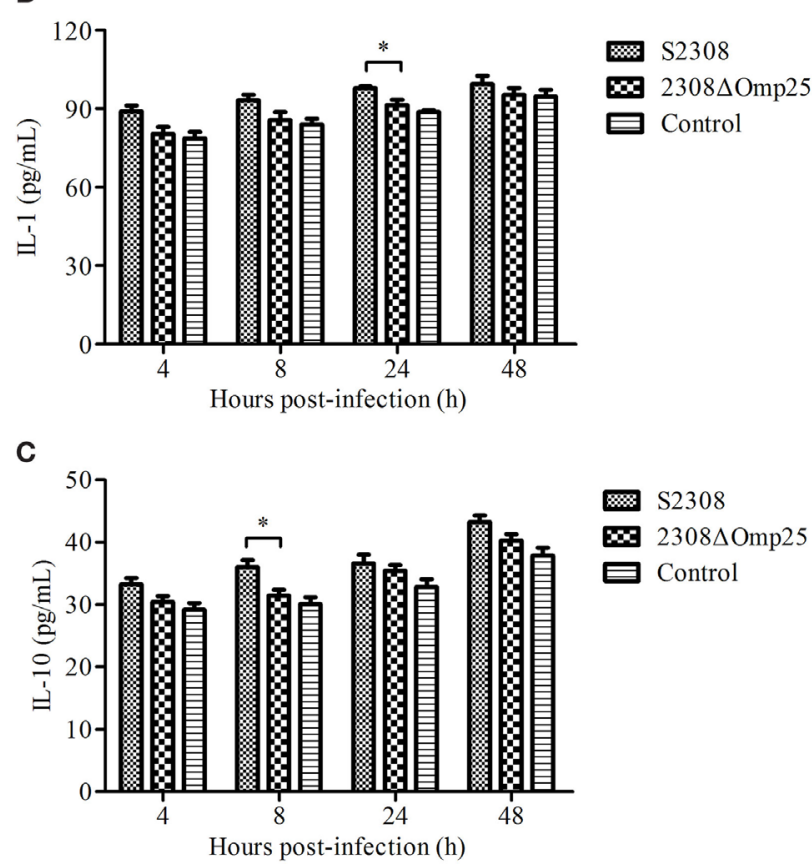

FIGURE 1 | Production of cytokines in $\$ 2308$ and $2308 \Delta$ Omp25-infected HPT-8 cells. HPT-8 cells were infected with $\mathrm{S} 2308$ or $2308 \Delta \mathrm{Omp} 25$ at a 100:1 MOI. Control group was uninfected. At 4, 8, 24, and $48 \mathrm{~h}$ post-infection, supernatant samples were collected and TNF- $\alpha$ (A), IL-1 (B), and IL-10 (C) levels were assayed by ELISA. Cytokines production is expressed as the mean cytokine concentration \pm SD for each group of cells. Significant differences between the S2308 and 2308 $\Delta$ Omp25 are indicated by * $(P<0.05)$. OMP25, outer membrane protein 25; IL-1, interleukin-1; IL-10, interleukin-10; MOI, multiplicity of infection; TNF- $\alpha$, tumor necrosis factor- $\alpha$. 


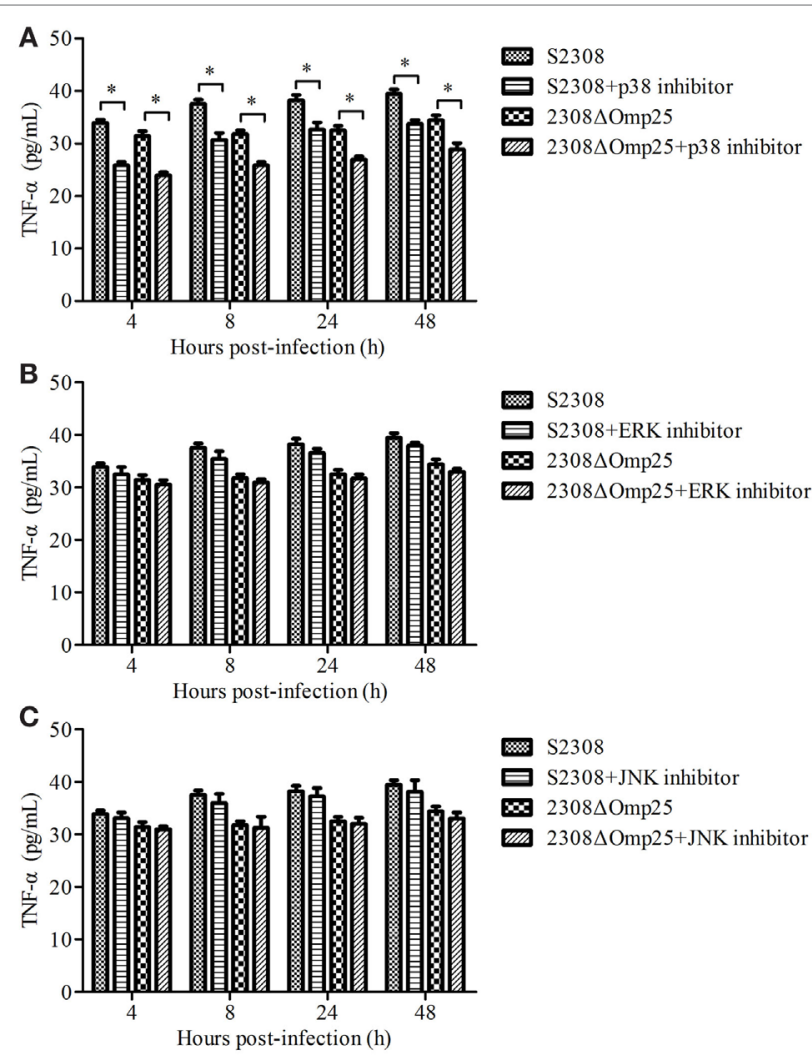

FIGURE 2 | Production of TNF- $\alpha$ in S2308 and 2308 OOmp25-infected HPT-8 cells. HPT-8 cells were pre-treated with p38 inhibitor $(10 \mu \mathrm{M})$ (A), ERK inhibitor $(10 \mu \mathrm{M}) \mathbf{( B )}$, or JNK inhibitor $(10 \mu \mathrm{M}) \mathbf{( C )}$ at $37^{\circ} \mathrm{C}$ for $1 \mathrm{~h}$ and then infected with S2308 or 2308 Omp25 at a 100:1 MOI. At 4, 8, 24, and $48 \mathrm{~h}$ post-infection, supernatant samples were collected and TNF- $\alpha$ levels were assayed by ELISA. TNF- $\alpha$ production is expressed as the mean cytokine concentration \pm SD for each group of cells. Significant differences between the S2308 and 2308 $\Delta$ Omp25 are indicated by * $(P<0.05)$. OMP25, outer membrane protein 25; JNK, Jun-N-terminal kinase; MOI, multiplicity of infection; TNF- $\alpha$, tumor necrosis factor- $\alpha$.

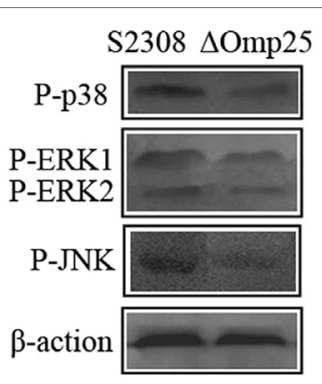

FIGURE 3 | Activation of p38, ERK1/2, and JNK kinases in S2308 and $2308 \Delta$ Omp25-infected HPT-8 cells. HPT-8 cells were infected with S2308 or $2308 \Delta \mathrm{Omp} 25$ at a 100:1 MOI. At $24 \mathrm{~h}$ post-infection, supernatant was discarded, and cells were lysed. Then, the activation of p38, ERK1/2, and JNK kinases was detected by Western blotting. Infections with $2308 \Delta \mathrm{Omp} 25$ induced a markedly weaker stimulation of p38, ERK1/2, and JNK kinases, with S2308 demonstrating a slightly higher capacity of activation than 2308 $\Delta$ Omp25. OMP25, outer membrane protein 25; JNK, Jun-N-terminal kinase; MOI, multiplicity of infection.

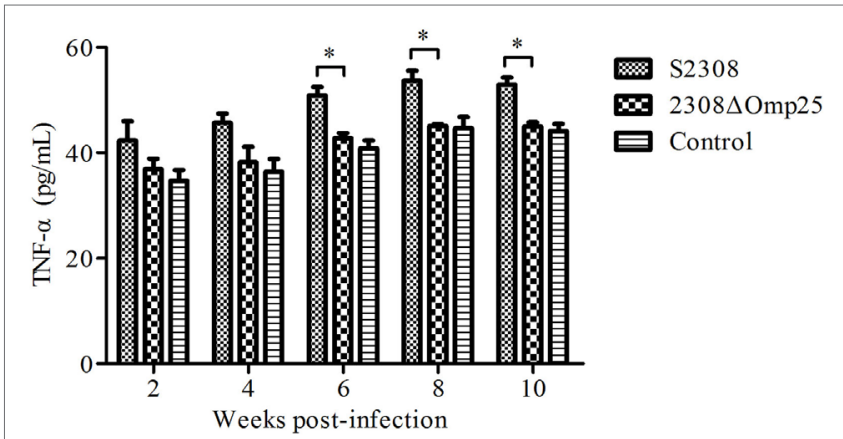

FIGURE 4 | Production of TNF- $\alpha$ in S2308 and $2308 \Delta$ Omp25 vaccinated BALB/c mice. BALB/c mice were inoculated with $1 \times 10^{6} \mathrm{CFU}$ of S2308 or 2308 $\Delta$ Omp25. Control groups received PBS. At 2, 4, 6, 8, and 10 weeks post-immunization, serum samples were collected ( $n=5$ per time point) and TNF- $\alpha$ levels were assayed by ELISA. TNF- $\alpha$ production is expressed as the mean cytokine concentration \pm SD for each group of mice. Significant differences between the $\mathrm{S} 2308$ and $2308 \Delta \mathrm{Omp} 25$ are indicated by * $(P<0.05)$. OMP25, outer membrane protein 25; TNF- $\alpha$, tumor necrosis factor- $\alpha$; PBS, phosphate-buffered saline.

analyzed by analysis of variance (ANOVA) followed by Tukey's honestly significant difference post-test, by comparing all the groups to one another. Results expressed as percentages were analyzed by the Fisher test. The differences between groups were analyzed by ANOVA using SPSS 17.0 software (SPSS, Inc., Chicago, IL, USA). $P$ values of $<0.05$ were considered statistically significant.

\section{RESULTS}

\section{Omp25 Induces Lower Levels of Cytokines}

To detect the expression level of cytokines, we collected supernatant from HPT-8 cells infected with S2308 and 2308 $\Delta$ Omp25 and then monitored expression levels of cytokine TNF- $\alpha$, IL-1, and IL- 10 by ELISA. Supernatant from HPT- 8 cells infected with S2308 produced higher amounts of TNF- $\alpha$ (Figure 1A), IL-1 (Figure 1B), and IL-10 (Figure 1C) than did supernatant from uninfected cells $(P<0.05)$ and this difference increased with time. Slightly higher cytokine production levels were observed in 2308 O Omp25-infected cells than in control cells (Figure 1), but there was no significant difference between $2308 \Delta$ Omp25 group and control group $(P>0.05)$.

\section{Expression of TNF- $\alpha$ Associated with p38 Branch}

We next evaluated which branch associated with secretion of TNF- $\alpha$. HPT- 8 cells were pre-incubated for $1 \mathrm{~h}$ with $10 \mu \mathrm{M}$ p38, $10 \mu \mathrm{M}$ ERK, or $10 \mu \mathrm{M}$ JNK inhibitors and then infected with S2308 or $2308 \Delta$ Omp25 for 4, 8, 24, and $12 \mathrm{~h}$. The levels of TNF- $\alpha$ were assessed in the supernatants of the S2308 or $2308 \Delta$ Omp25-infected p38 inhibitor, ERK inhibitor or JNK inhibitor-treated cells. At 4, 8, 24, and $12 \mathrm{~h}$, the S2308 or 2308 $\Delta$ Omp25-infected p38 inhibitor-treated cells produced higher levels of TNF- $\alpha$ than S2308 or $2308 \Delta$ Omp25-infected 


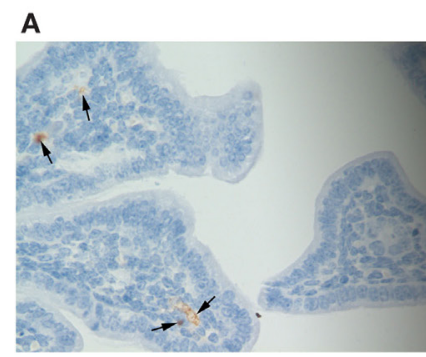

$2 \mathrm{~W}$

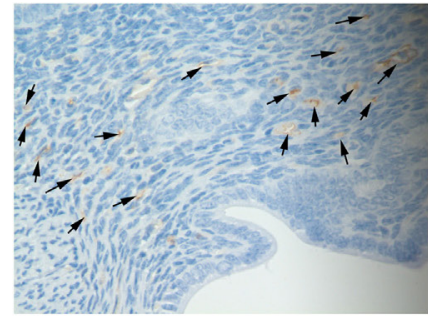

$8 \mathrm{~W}$

B

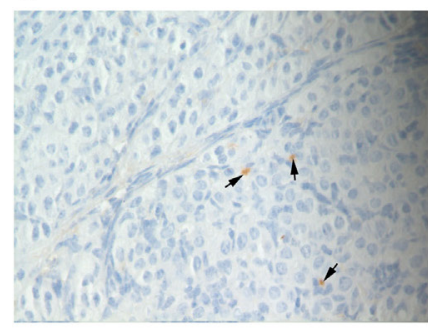

2W

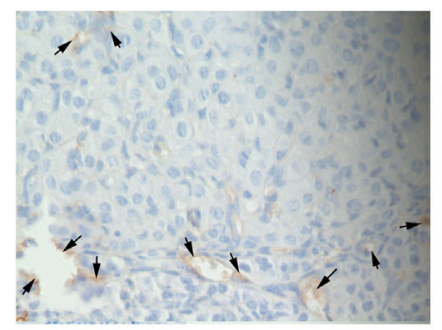

8W

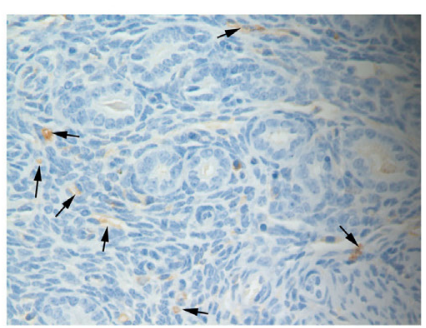

4W

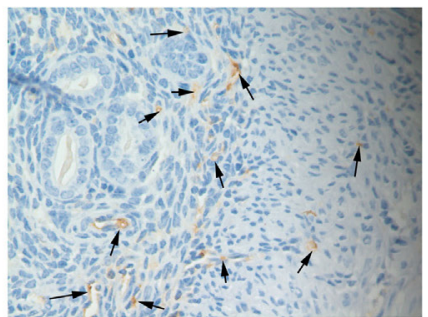

$10 \mathrm{~W}$

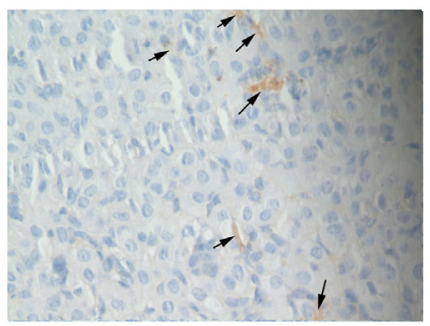

4W

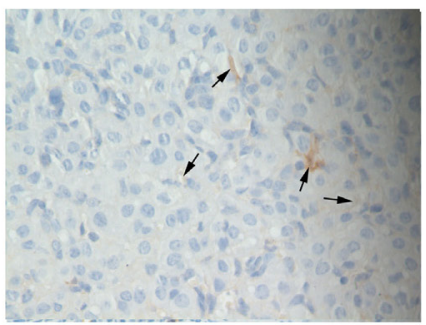

10W

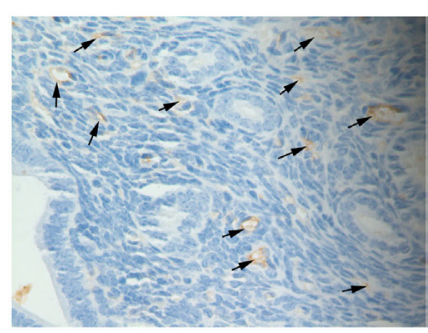

$6 \mathrm{~W}$

FIGURE 5 | Immunohistochemical detection of phosphorylation proteins in p38 signal pathway branch. BALB/c mice were inoculated with $1 \times 10^{6} \mathrm{CFU}$ of S2308 or 2308 Omp25. At 2, 4, 6, 8, and 10 weeks post-immunization, uterus tissues were removed and detected by immunohistochemistry. The phosphorylation proteins in p38 signal pathway had been detected and found in the uterus tissues of S2308 immunized mice (A). But the immune complexes of phosphorylation proteins in p38 signal pathway were weakly stained in the uterus tissues of 2308 $\mathrm{Omp} 25$ immunized mice (B). OMP25, outer membrane protein 25.

cells $(P<0.05$; Figure 2A). However, there was no significant difference between S2308 or 2308 $\Delta$ Omp25-infected ERK inhibitor and JNK inhibitor-treated cells and S2308 or 2308 OOmp25infected cells $(P>0.05$; Figures 2B,C). These results showed that p38 branch could induce secretion of TNF- $\alpha$ in S2308 or 2308 Omp25-infected cells.

\section{Omp25 Activates Weak MAPK Pathway}

To assess activation of p38 and ERK1/2 kinases, HPT- 8 cells were infected with the $2308 \Delta \mathrm{Omp} 25$ mutant and the parental strain S2308 at a MOI of 100 . We found that at $24 \mathrm{~h}$ post-infection, the activation process triggered by S2308 resulted in a phosphorylation of the p38, ERK1/2, and JNK kinases (Figure 3). Infections with $2308 \Delta$ Omp25 induced a markedly weaker stimulation of p38, ERK1/2, and JNK kinases, with S2308 demonstrating a slightly higher capacity of activation than $2308 \Delta$ Omp 25 mutant (Figure 3). These results show that OMP25 involved in activating of MAPK pathway.

\section{Omp25 Induces Lower Levels of TNF- $\alpha$ in Peripheral Blood of Mice}

To detect the expression level of TNF- $\alpha$ in animal, we collected sera from mice inoculated with S2308, 2308 OMp25, or PBS 
A

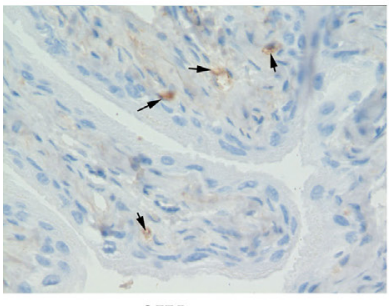

$2 \mathrm{~W}$

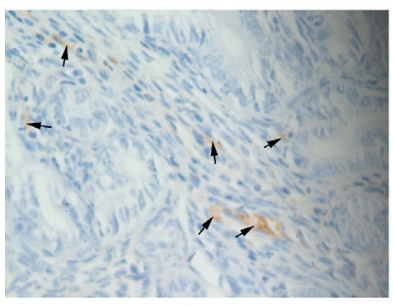

$8 \mathrm{~W}$

B

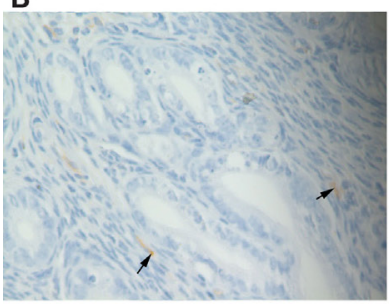

$2 \mathrm{~W}$

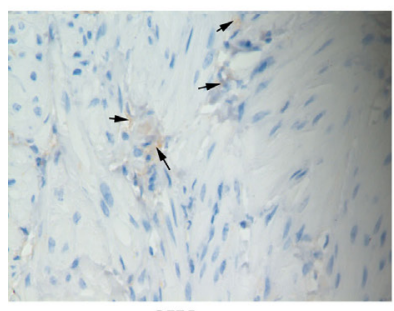

$8 \mathrm{~W}$

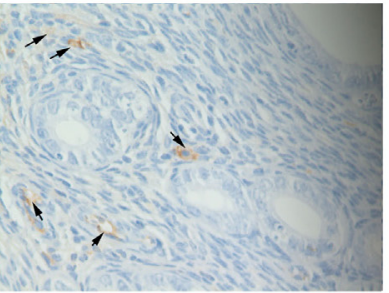

$4 \mathrm{~W}$

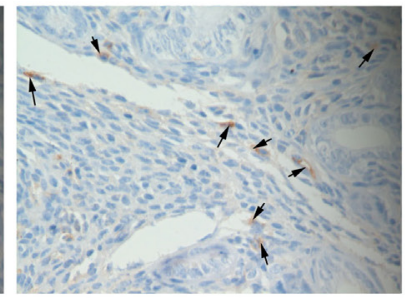

$10 \mathrm{~W}$

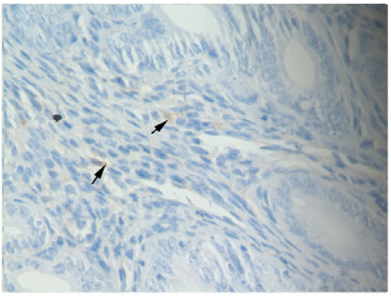

$4 \mathrm{~W}$

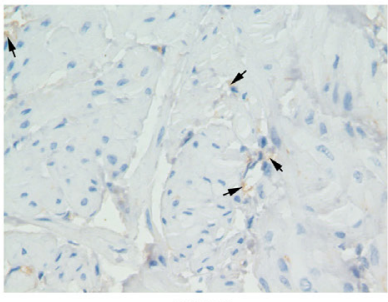

$10 \mathrm{~W}$

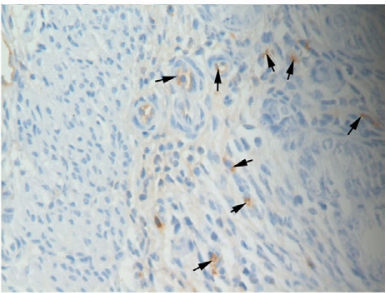

$6 \mathrm{~W}$

FIGURE 6 | Immunohistochemical detection of phosphorylation proteins in ERK signal pathway branch. BALB/c mice were inoculated with $1 \times 10^{6} \mathrm{CFU}$ of S2308 or $2308 \Delta$ Omp25. At 2, 4, 6, 8, and 10 weeks post-immunization, uterus tissues were removed and detected by immunohistochemistry. The phosphorylation proteins in ERK signal pathway had been detected and found in the uterus tissues of S2308 immunized mice (A). But the immune complexes of phosphorylation

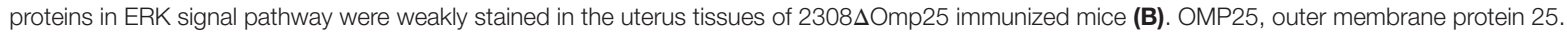

and then measured expression levels of TNF- $\alpha$ by ELISA. Serum samples from mice inoculated with S2308 produced higher amounts of TNF- $\alpha$ (Figure 4) than did serum samples from mice inoculated with $2308 \Delta$ Omp 25 or PBS $(P<0.05)$ and this difference increased with time. Slightly higher cytokine production levels were observed in $2308 \Delta$ Omp25 immunized mice than in PBS immunized mice $(P>0.05)$ (Figure 4). Total TNF- $\alpha$ levels increased with time.

\section{Immunohistochemical Staining}

The immune complexes of p38 and ERK phosphorylation proteins were located in the cytoplasm of the uterus tissues, and they were strongly stained as tan or brownish yellow. The phosphorylation proteins in $\mathrm{p} 38$ and ERK signal pathways had been detected and found in the uterus tissues of S2308 immunized mice (Figures 5A and 6A). But the immune complexes of phosphorylation proteins in p38 and ERK signal pathways were weakly stained in the uterus tissues of $2308 \Delta$ Omp25 immunized mice (Figures 5B and 6B). These results showed that S2308 was able to activate phosphorylation of p38 and ERK in BABL/c mice. However, $2308 \Delta$ Omp25 could weakly activate phosphorylation of p38 and ERK.

\section{DISCUSSION}

Brucella could infect many kinds of cells, but the main host cells are macrophages and trophoblasts (26). In animals, abortion is associated with a rapid proliferation of Brucella within the placenta. Trophoblasts are primary cellular targets for Brucella in the natural host. The presence of high bacterial loads within 
placental trophoblasts ultimately results in disruption of the placenta and infection of the fetus. Omps of Brucella play an important role in the process of pathogen (27). Omp25 an important Omp, it involved in growth, colonization, and proliferation of Brucella (28). The Omp25 mutant strain attenuated Brucella infection abilities and changed the response of host cells (10). TNF- $\alpha$ is one of important factors that involved in many of the body's immune and inflammatory responses (29). The expression of TNF- $\alpha$ was related with Omp25 and ERK pathway (27). Our results found that there was a significant difference in the expression of TNF- $\alpha$ between S2308 and $2308 \Delta$ Omp25. These results suggested that Omp25 may play an important role in the progress of expression of TNF- $\alpha$ when Brucella infected cells.

Phosphorylation of MAPK p38 pathway acts as a "switch" role in regulating the production of cytokines. The whole process is through a typical pathway: MAPKKK $\rightarrow$ MAPKK $\rightarrow$ MAPK (12). SB208035 is the inhibitor of p38 signal pathway. It has been reported that $\mathrm{p} 38$ inhibitors could inhibit the production of IL-1, IL-10, and TNF- $\alpha$ in peripheral blood cells (30). TNF- $\alpha$ could activate p38 pathway (31). Our results showed that $2308 \Delta$ Omp25 was weaker to activate p38 pathway in MAPK signal pathway than S2308. The reason may be the low expression of TNF- $\alpha$ in $2308 \Delta$ Omp25. It suggested that the production of TNF- $\alpha$ may be related with the activation of p38 pathway. When we used p38 inhibitors to deal with HPT- 8 cells, and detected the expression of TNF- $\alpha$ in the culture medium. We found that the expression of TNF- $\alpha$ has been inhibited. It suggested that when S2308 or 2308 OOmp25-infected HPT-8 cells, the p38 pathway in the MAPK signal pathway was related with the expression of TNF- $\alpha$.

Brucella can lead many organs happening pathological damages, particularly in chronic infection stage. In the experiment, we found that the expressions of TNF- $\alpha$ significantly increased when S2308 or $2308 \Delta$ Omp25-infected mice or HPT-8 cells. It showed that TNF- $\alpha$ was one of cytokines that happened significantly change when Brucella infected hosts (organisms and cells), and it may be related to the progress of inflammation. From the result of immunohistochemistry, we found that phosphorylation proteins of p38 and ERK signal pathway in uterine tissues of mice. In addition, we also found that the

\section{REFERENCES}

1. Pappas G, Akritidis N, Bosilkovski M, Tsianos E. Brucellosis. N Engl J Med (2005) 352:2325-36. doi:10.1056/NEJMra050570

2. Lacerda TLS, Cardoso PG, Augusto de Almeida L, Camargo IL, Afonso DAF, Trant CC, et al. Inactivation of formyltransferase (wbkC) gene generates a Brucella abortus rough strain that is attenuated in macrophages and in mice. Vaccine (2010) 28:5627-34. doi:10.1016/j.vaccine.2010.06.023

3. Ficht TA. Intracellular survival of Brucella: defining the link with persistence. Vet Microbiol (2003) 92:213-23. doi:10.1016/S0378-1135(02)00367-X

4. Elzer PH, Hagius SD, Davis DS, DelVecchio VG, Enright FM. Characterization of the caprine model for ruminant brucellosis. Vet Microbiol (2002) 90: 425-31. doi:10.1016/S0378-1135(02)00226-2

5. Godfroid J, Cloeckaert A, Liautard JP, Kohler S, Fretin D, Walravens K, et al. From the discovery of the Malta fever's agent to the discovery of a marine mammal reservoir, brucellosis has continuously been a re-emerging zoonosis. Vet Res (2005) 36:313-26. doi:10.1051/vetres:2005003 immune complexes of phosphorylation proteins in p38 and ERK signal pathways were weakly stained in the uterus tissues of $2308 \Delta$ Omp25 immunized mice. These results suggested that Omp25 participated in phosphorylation of p38 and ERK signal pathway proteins. Previous studies have reported that the MAPKs are a target for immune intervention by virulent smooth Brucella (32). Our results further suggest that Omp25 played an important role in activating MAPK signal pathway in smooth Brucella.

In conclusion, we found that Brucella can affect the expression of TNF- $\alpha$ by activating MAPK signal pathway, and the expression was higher in S2308 than 2308 $\Delta$ Omp25. It suggested that Omp 25 played an important role in activating MAPK signal pathway when Brucella infected hosts. These results established theoretical foundation for further studying pathogenic mechanisms and proinflammatory mechanisms of Brucella.

\section{ETHICS STATEMENT}

The study was approved by the Institutional Committee of Post-Graduate Studies and Research at Shihezi University, China (No. 2012-9). All efforts were made to minimize animal suffering.

\section{AUTHOR CONTRIBUTIONS}

JZ, YZ, LL, and HZ designed the experiments. ZL, JL, YW, TL, and LL performed the experiments and analyzed the data. XS, KW, CW, LL, CC, and HZ contributed reagents/materials/ analysis tools. JZ, YZ, ZL, LL, and HZ wrote and revised the paper.

\section{FUNDING}

This work was supported by grants from the National key Research and Development Program of China (2017YFD0500304), the National Natural Science Foundation of China (31460650, 31602080, 31360610, and 31402166), the Training Program for Excellent Young Teachers Colleges and Universities of Corps (CZ027202), the Foundation of the Technology Department of Henan Province (172102310335), and the Foundation of the Education Department of Henan Province (16A230013).

6. Pappas G. The changing Brucella ecology: novel reservoirs, new threats. Int J Antimicrob Agents (2010) 36(Suppl 1):S8-11. doi:10.1016/j.ijantimicag.2010.06.013

7. Cloeckaert A, Vizcaino N, Paquet JY, Bowden RA, Elzer PH. Major outer membrane proteins of Brucella spp.: past, present and future. Vet Microbiol (2002) 90:229-47. doi:10.1016/S0378-1135(02)00211-0

8. Edmonds MD, Cloeckaert A, Elzer PH. Brucella species lacking the major outer membrane protein Omp25 are attenuated in mice and protect against Brucella melitensis and Brucella ovis. Vet Microbiol (2002) 88:205-21. doi:10.1016/S0378-1135(02)00110-4

9. Edmonds MD, Cloeckaert A, Booth NJ, Fulton WT, Hagius SD, Walker JV, et al. Attenuation of a Brucella abortus mutant lacking a major $25 \mathrm{kDa}$ outer membrane protein in cattle. Am J Vet Res (2001) 62:1461-6. doi:10.2460/ ajvr.2001.62.1461

10. Edmonds MD, Cloeckaert A, Hagius SD, Samartino LE, Fulton WT, Walker JV, et al. Pathogenicity and protective activity in pregnant goats of a Brucella melitensis Deltaomp25 deletion mutant. Res Vet Sci (2002) 72:235-9. doi:10.1053/ rvsc. 2002.0555 
11. Pizarro-Cerda J, Meresse S, Parton RG, van der Goot G, Sola-Landa A, Lopez-Goni I, et al. Brucella abortus transits through the autophagic pathway and replicates in the endoplasmic reticulum of nonprofessional phagocytes. Infect Immun (1998) 66:5711-24.

12. Johnson GL, Lapadat R. Mitogen-activated protein kinase pathways mediated by ERK, JNK, and p38 protein kinases. Science (2002) 298:1911-2. doi:10.1126/ science. 1072682

13. Hobbie S, Chen LM, Davis RJ, Galan JE. Involvement of mitogen-activated protein kinase pathways in the nuclear responses and cytokine production induced by Salmonella typhimurium in cultured intestinal epithelial cells. J Immunol (1997) 159:5550-9.

14. Palmer LE, Hobbie S, Galan JE, Bliska JB. YopJ of Yersinia pseudotuberculosis is required for the inhibition of macrophage TNF-alpha production and downregulation of the MAP kinases p38 and JNK. Mol Microbiol (1998) 27: 953-65. doi:10.1046/j.1365-2958.1998.00740.x

15. Ruckdeschel K, Harb S, Roggenkamp A, Hornef M, Zumbihl R, Kohler S, et al. Yersinia enterocolitica impairs activation of transcription factor NF-kappaB: involvement in the induction of programmed cell death and in the suppression of the macrophage tumor necrosis factor alpha production. J Exp Med (1998) 187:1069-79. doi:10.1084/jem.187.7.1069

16. Tang P, Rosenshine I, Cossart P, Finlay BB. Listeriolysin O activates mitogen-activated protein kinase in eukaryotic cells. Infect Immun (1996) 64:2359-61.

17. Tang P, Sutherland CL, Gold MR, Finlay BB. Listeria monocytogenes invasion of epithelial cells requires the MEK-1/ERK-2 mitogen-activated protein kinase pathway. Infect Immun (1998) 66:1106-12.

18. Schorey JS, Cooper AM. Macrophage signalling upon mycobacterial infection: the MAP kinases lead the way. Cell Microbiol (2003) 5:133-42. doi:10.1046/j.1462-5822.2003.00263.x

19. Li DQ, Luo L, Chen Z, Kim HS, Song XJ, Pflugfelder SC. JNK and ERK MAP kinases mediate induction of IL-1beta, TNF-alpha and IL-8 following hyperosmolar stress in human limbal epithelial cells. Exp Eye Res (2006) 82:588-96. doi:10.1016/j.exer.2005.08.019

20. Hernández-Castro R, Verdugo-Rodríguez A, Luis Puente J, SuárezGüemes F. The BMEI0216 gene of Brucella melitensis is required for internalization in HeLa cells. Microb Pathog (2008) 44:28-33. doi:10.1016/j.micpath. 2007.08.008

21. Zhang JB, Guo F, Chen CF, Jian T, Yin SH, Zhang H, et al. Ubiquitin-like protein SUMO-1 is essential for the survival of Brucella melitensis 16M inside RAW264.7 macrophages. Pak Vet J (2014) 34:314-8.

22. Li Z, Shi J, Fu W, Zhang Y, Zhang J, Wang Z, et al. A Brucella melitensis M5-90 wboA deletion strain is attenuated and enhances vaccine efficacy. Mol Immunol (2015) 66:276-83. doi:10.1016/j.molimm.2015.04.004

23. Zhang X, Ge Y, Zhao S, Hu Y, Ashman RB. Immunisation with the glycolytic enzyme enolase confers effective protection against Candida albicans infection in mice. Vaccine (2011) 29:5526-33. doi:10.1016/j.vaccine.2011. 05.030
24. Nambiar PR, Kirchain SM, Courmier K, Xu S, Taylor NS, Theve EJ, et al. Progressive proliferative and dysplastic typhlocolitis in aging Syrian hamsters naturally infected with Helicobacter spp.: a spontaneous model of inflammatory bowel disease. Vet Pathol (2006) 43:2-14. doi:10.1354/ vp.43-1-2

25. Yuan M, Li Y, Zhong C, Li Y, Niu J, Gong J. Overexpression of neuritin in gastric cancer. Oncol Lett (2015) 10:3832-6. doi:10.3892/ol.2015.3793

26. von Bargen K, Gorvel JP, Salcedo SP. Internal affairs: investigating the Brucella intracellular lifestyle. FEMS Microbiol Rev (2012) 36:533-62. doi:10.1111/ j.1574-6976.2012.00334.x

27. Jubier-Maurin V, Boigegrain RA, Cloeckaert A, Gross A, Alvarez-Martinez MT, Terraza A, et al. Major outer membrane protein Omp25 of Brucella suis is involved in inhibition of tumor necrosis factor alpha production during infection of human macrophages. Infect Immun (2001) 69:4823-30. doi:10.1128/ IAI.69.8.4823-4830.2001

28. Cloeckaert A, Zygmunt MS, Bezard G, Dubray G. Purification and antigenic analysis of the major 25-kilodalton outer membrane protein of Brucella abortus. Res Microbiol (1996) 147:225-35. doi:10.1016/0923-2508(96)81383-0

29. Ma QL, Liu AC, Ma XJ, Wang YB, Hou YT, Wang ZH. Brucella outer membrane protein Omp25 induces microglial cells in vitro to secrete inflammatory cytokines and inhibit apoptosis. Int J Clin Exp Med (2015) 8: 17530-5.

30. Foey AD, Parry SL, Williams LM, Feldmann M, Foxwell BM, Brennan FM. Regulation of monocyte IL-10 synthesis by endogenous IL-1 and TNF-alpha: role of the p38 and p42/44 mitogen-activated protein kinases. JImmunol (1998) 160:920-8.

31. Zu YL, Qi J, Gilchrist A, Fernandez GA, Vazquezabad D, Kreutzer DL, et al. p38 mitogen-activated protein kinase activation is required for human neutrophil function triggered by TNF- $\alpha$ or FMLP stimulation. J Immunol (1998) 160:1982-9.

32. Jiménez de Bagüés MP, Gross A, Terraza A, Dornand J. Regulation of the mitogen-activated protein kinases by Brucella spp. expressing a smooth and rough phenotype: relationship to pathogen invasiveness. Infect Immun (2005) 73:3178-83. doi:10.1128/IAI.73.5.3178-3183.2005

Conflict of Interest Statement: The authors declare that the research was conducted in the absence of any commercial or financial relationships that could be construed as a potential conflict of interest.

Copyright (c) 2017 Zhang, Zhang, Li, Liu, Shao, Wu, Wang, Wang, Li, Liu, Chen and Zhang. This is an open-access article distributed under the terms of the Creative Commons Attribution License (CC BY). The use, distribution or reproduction in other forums is permitted, provided the original author(s) or licensor are credited and that the original publication in this journal is cited, in accordance with accepted academic practice. No use, distribution or reproduction is permitted which does not comply with these terms. 